\title{
Regarding the Issue of Insurance Market in Slovak Republic Being a Part of Financial Market
}

\author{
Barbora Drugdová \\ Department of Insurance, Faculty of National Economics, University of Economics in Bratislava, Slovakia
}

Copyright $(2016$ by authors, all rights reserved. Authors agree that this article remains permanently open access under the terms of the Creative Commons Attribution License 4.0 International License.

\begin{abstract}
The article focuses on the commercial insurance of non-life risks and non-life commercial insurance market as part of the financial market in the Slovak Republic. The Slovak commercial insurance market is well-developed. There were 21 commercial insurance companies, and all of them were all associated in the Association of Slovak Insurance Companies and operated in the Slovak Republic until December 31, 2014. Development of insurance in the area of life insurance in recent years is more dynamic than in non-life insurance. The Slovak Republic is gradually closer to the European average on the insurance market, which is about 62 percent in favour of life insurance. Commercial insurers offer a wide variety of insurance products. Amongst them are also products aimed at insuring international risks, as a part of non-life risks.
\end{abstract}

Keywords Commercial Insurance Market, Insurance of Non-life Risks, International Risks, Company Insurance Indicators, Insurance Products

\section{Introduction}

At present, our society is undergoing a period of important changes in both the social and economic fields. The Slovak insurance sector has gone through a period that has significantly affected its development by economic changes, mainly by the introduction of the market economy and the privatization of state-owned property. The development of the insurance market in Slovakia accelerated after 1990, when Slovenská Poist'ovňa lost its monopoly position. An important landmark in the insurance field was the adoption of the Act of the National Council of the SR No. 24/1991 Coll. on Insurance, as amended by subsequent legislation. Slovenská Štátna Poist'ovňa was first turned into a state-owned company, and as of January 1, 1992 it became a joint-stock company with the name of Slovenská Poist'ovňa, a.s. In the process of demonopolization of the insurance business, other insurance companies, in the form of joint-stock companies, were formed (Kooperativa, Otčina,
Union, and so forth). Also, several foreign insurance companies obtained a license to operate on the territory of Slovakia, usually founding subsidiaries here.

The Act No. 24/1991 Coll. created conditions for the democratization of the insurance business, enabled the entry of foreign capital, and thereby the formation of a competitive environment in the insurance market. In this Act, the supervision over insurance businesses has been established. The position of the authority supervising the insurance business has been delineated by the Act No. 25/1991 Coll.

Another legislative step was the adoption of the Act of the National Council, SR No. 306/1995 Coll., amending Act No. 24/1991 Coll. on Insurance Business. The transition from special insurance funds to reserves has been made thereunder. A solvency tool for insurance companies conforming to the standards in place in developed countries has been introduced. Another legislative step was Act No. 95/2002 Coll. on Insurance Business, Act No. 8/2008 Coll. on Insurance Business and Act No. 39/2015 Coll. on Insurance Business.

Since 1 May 2004, the Slovak insurance market has been part of the uniform European Union insurance market, which includes over 5,000 insurance companies. After Slovakia's admission to the European Union, several legislative changes have been adopted in the area of commercial insurance industry, which also influenced non-life and life insurance and the insurance of international risks as part of non-life risks. The most recent act in the area of commercial insurance mentioned in the paper is the Act of the National Council SR No. 39/2015 Coll. on Insurance, in which there are legislative changes in life and also non-life insurance.

\section{The Insurance Market Part of the Financial Market}

The insurance market is a part of the financial market. Besides the insurance market, the financial market is comprised of the money market, capital market, foreign exchange market, and market in precious metals. The division of the financial market into the five said segments is purpose-oriented and historically limited. It needs to be 
mentioned that no sharp dividing line can be made between the respective financial market segments. These segments are interlinked by tools, entities, operations, ownership, and the like.

The insurance market, being a segment of the financial market, is characterized by certain special features. It represents a system of different market tools and regulatory measures, which provide for the flow of funds and insurance services between insurance market participants in accordance with the principle of conditional recovery and non-equivalence.

The insurance market is the place at which supply and demand for insurance protection meet.

Insurance services, i.e. services of insurance protection, are specific goods sold on the insurance market. A need for insurance protection arises in each society due to the existence of different risks. Such risks have objective and subjective character and are divided accordingly.

The insurance sector, as one of the branches of the national economy, offers its goods (money services, i.e. insurance) on the insurance market. Insurance helps to resolve the main problems that may arise as a result of extraordinary and unexpected events. By this token, insurance performs the function of stabilizing the economic standard of business entities and the standard of living of private persons and has an irreplaceable part to play in the financial management of businesses and family budgets. The basis of insurance lies in the objective existence of risks that pose a danger to nature and any human activity. Humans should naturally strive to reduce the risks and the likelihood of losses caused thereby. Nevertheless, if we were to take the population of Slovakia, being the main market entity, as a whole, we would find out that insurance ranks the lowest in their personal consumption ladder. It needs to be mentioned that the proportion of life assurance to nonlife insurance is unsatisfactory in Slovakia compared to developed economies. As an example, this proportion in Japan is 78 to 22, in England it is 67 to 33 and in France 61 to 39 (CEA Number of companies, 2014). In Slovakia, the proportion of life assurance to nonlife insurance is 54 to 46 .

Depending on the line of its business, an insurance company may carry out two different types if activities, namely those in the insurance market itself, i.e. matching insurance supply and demand, and in the investment insurance market, being a part of the financial market, i.e. investing free funds.

Business objects pursued by an insurance company in the insurance market proper consist of insurance, reinsurance and other associated activities.

The investment insurance market is based on the fact that insurance operates on the principle of raising reserves to eliminate the negative financial impacts of random events on the insured. Each insurance company must try to behave as a business entity and invest temporarily free funds so as to make profit. The insured, in their role of indirect market participants, must believe that their insurance company will find the right niche in the financial market in which to place the money.

\section{The Commercial Insurance Market in Slovakia}

The insurance market in developed economies is populated by many insurance companies. Each of them gets involved in this market by offering different insurance products and is interested in covering the widest possible segment (insurance market coverage). Competitor insurance companies keep track of the size of the insurance market covered and try to gain as large a share in it as possible by offering new types of insurance products.

Numerous commercial insurance companies operate on the commercial insurance market in advanced economies. Each of them participates in this market with a different offer of insurance products and attempts to cover the largest possible space (insurance field). ${ }^{1}$ As at 31 December2014 as mentioned before, as many as twenty-one commercial insurance companies operated on the Slovak insurance market; all of them were associated in the Slovak Association of Insurers and recorded technical insurance premium indicators, as shown in Table 1 (Table 1: Technical premium in total and in technical insurance premium in non-life insurance as at 31 December 2014 in thousands $€$ ). Commercial insurance companies offering insurance products in the area of international risks participated in non-life insurance with the following data.

The total of technical insurance premium for all insurance products in the year 2014 was 2,180,899 thousand Euros. Table 1 entitled "Technical Premium in total and in nonlife insurance in commercial insurance companies as at31 December 2014in thousand $€^{2}$ " shows also the succession of commercial insurance companies on the Slovak insurance market in the year 2014. The primacy in non-life insurance on the Slovak insurance market was held by Allianz Slovenská Poist'ovňa, a. s., with $34.51 \%$, which accounted for 333,118 thousand Euros. The second place was occupied by KOOPERATÍVA insurance company, a. s., VIG in non-life insurance with $26.43 \%$, which accounted for 255,111 thousand Euros, and the third place in non-life insurance by Generali Slovensko, insurance company, a. s. with $9.91 \%$, which is equal to 95,669 thousand Euros.

Insurance products designed for insuring international risks belong in the area of non-life insurance. The insurance company Allianz - Slovenská Poist'ovňa, a. s. has the widest offer of insurance products designed for the insurance of international risks. In the year 2014 the commercial insurance company Allianz - Slovenská Poistovña, a.s. achieved primacy in the total technical insurance premium for all the insurance products, which amounted to 586,308

1 Note: Commercial insurance companies offer insurance products of life and non-life insurance on the insurance market. Non-life insurance products are more numerous, this is due to the fact that the number of risks of non-life character is higher in economic practice. These risks also include international risks.

2 Source: www.slaspo.sk 
thousand Euros and reached 26.88\% share of the total commercial insurance market.

The most important insurance products in the area of international risks offered by commercial insurance companies on the commercial insurance market are: transportation insurance (insurance of international transportation of consignments), insurance of investment unit (building and assembly insurance), insurance of exhibitions and fairs, product liability insurance, insurance of international road carrier, motor hull insurance for travel abroad, aircraft operation insurance, and special risks insurance. Special risks include mainly: insurance of equipment of nuclear industry and of allied perils, export credit insurance, insurance of caution money, insurance of early delivery of goods to a foreign buyer, and insurance of shipping charges.

Another group, which we classify in the area of international risks, relates to insurance of persons, namely: insurance of tourist risks, tourism insurance, insurance of medical expenses incurred abroad, and the like.

Table 1. Technical Premium in total and in nonlife insurance in commercial insurance companies as at 31 December 2014 in thousand $€^{3}$

\begin{tabular}{|c|c|c|c|}
\hline & Technical premium as at 31 December 2014 in thousand $€$ & & \\
\hline No & Commercial Insurance company & $\begin{array}{l}\text { Technical premium } \\
\text { total for all insurance } \\
\text { products } \\
\end{array}$ & $\begin{array}{l}\text { Technical premium in } \\
\text { non life insurance for } \\
\text { insurance products }\end{array}$ \\
\hline 1 & AEGON Life Insurance company & 42092 & 0 \\
\hline 2 & Allianz - Slovenská Insurance company, a. s. & 586308 & 333118 \\
\hline 3 & $\begin{array}{l}\text { AXA Life Insurance company, branch of an insurance company in another } \\
\text { member state }\end{array}$ & 52524 & 5519 \\
\hline 4 & $\begin{array}{l}\text { AXA Insurance company branch of an insurance company in another member } \\
\text { state }\end{array}$ & 10226 & 10226 \\
\hline 5 & $\begin{array}{l}\text { BASLER Lebensversicherung - AG branch of an insurance company in } \\
\text { another member state }\end{array}$ & 5838 & 0 \\
\hline 6 & $\begin{array}{l}\text { BASLER Sachversicherung - AG branch of an insurance company in another } \\
\text { member state }\end{array}$ & 4067 & 4067 \\
\hline 7 & ČSOB insurance company, a. s. & 80870 & 28170 \\
\hline 8 & $\begin{array}{l}\text { D.A.S. Rechtsschutz AG, branch of an insurance company in another member } \\
\text { state }\end{array}$ & 2643 & 2643 \\
\hline 9 & ERGO Insurance company, a.s. & 34082 & 1563 \\
\hline 10 & Generali Slovakia Insurance company, a. s. & 174000 & 95669 \\
\hline 11 & $\begin{array}{l}\text { Groupama Garancia Insurance company, a.s., branch of an insurance company } \\
\text { in another member state }\end{array}$ & 4514 & 3992 \\
\hline 12 & ING Life Insurance company, a. s. & 75951 & 0 \\
\hline 13 & KOMUNÁLNA Insurance company, a. s. VIG & 176840 & 66401 \\
\hline 14 & KOOPERATIVA Insurance company, a. s., VIG & 477673 & 255111 \\
\hline 15 & Met Life insurance company, a.s. & 124738 & 8964 \\
\hline 16 & Cardif Slovakia, Insurance company a.s. & 23049 & 16834 \\
\hline 17 & Insurance company of the Poštová Banka, a. s. & 10805 & 1148 \\
\hline 18 & Insurance company of the Slovenská Sporitel'ňa, a. s., VIG & 80632 & 0 \\
\hline 19 & UNION insurance company, a. s. & 40946 & 31185 \\
\hline 20 & UNIQA insurance company, a. s. & 112723 & 80641 \\
\hline 21 & Wüstenrot insurance company & 60371 & 22093 \\
\hline \multirow[t]{2}{*}{22} & Slovak Insurers Office & 8 & 8 \\
\hline & Total & $2,180,899$ & 965,351 \\
\hline
\end{tabular}




\section{Conclusions}

The total of technical insurance premium for all insurance products in the year 2014 was 2,180,899 thousand Euros. Table 1 entitled Technical Premium in total and in no life insurance in commercial insurance companies as at31 December 2014in thousand $€$ i, shows also the succession of commercial insurance companies on the Slovak insurance market in the year 2014. The primacy in non-life insurance on the Slovak insurance market was held by Allianz Slovenská Poist'ovňa, a. s., with $34.51 \%$, which accounted for 333,118 thousand Euros. In connection with the insurance of international risks, as part of non-life risks, it has to be mentioned that commercial insurance companies on the Slovak insurance market do not offer some insurance used in European Union countries, in particular in Great Britain, Germany and France, and in the entire advanced world, mainly in Japan and in the United States. They are in particular insurance products from the area of commercial risks (e.g. banking and financial risks) and also insurance products that belong to the special kinds of risks (e.g. natural catastrophes risks and technical disasters, as well as risks of terrorist attacks and the like.)

\section{Acknowledgements}

This paper was created on the basis of the financial support of the grant project VEGA Ministry of Education of the Slovak Republic, Project No. 1/0236/15.

\section{REFERENCES}

[1] Bland, D. (2003).Insurance principles and practice. London: The Chartered Insurance Institute.

[2] Breveníková, D. - Čejková, V. - Ondrejová, Z. (1995).Poistenie a poistovníctvo. Anglicko - slovenský aslovensko - anglický slovník. Bratislava : Publ. ELITA, $184 \mathrm{pp}$.

[3] Drugdová, B. (1995). Poistenie a poistovníctvo, nemecko slovenský a slovensko - nemecký slovník. Bratislava: ELITA, $186 \mathrm{pp}$

[4] Drugdová, B. (2013). Business Insurance. Bratislava: ŠEVT, $201 \mathrm{pp}$.

[5] WAUGHAN, E. J.(1992). Fundamentals of Risk and Insurance. New York: John Wiley and Sons, Canada, Limited 1992. 286pp

[6] GREENE, H.(2013).Risk and insurance, The University of Georgia, Cincinnati, Ohio, 239pp

[7] www.slaspo.sk

[8] www.cap.cz.

[9] www.nbs.sk

i Source: www.slaspo.sk 